\title{
RELIGIOUS TOURISM IN THE SOUTH-MORAVIAN AND ZLIIN REGIONS: PROPOSAL FOR THREE NEW PILGRIMAGE ROUTES
}

\author{
Miroslav Horák ${ }^{1}$, Alice Kozumplíková2, Kristína Somerlíková3 ${ }^{3}$ Helena \\ Lorencová ${ }^{\text {, Ivana Lampartová }}{ }^{5}$
}

Received 11 September 2015; Accepted 25 November 2015

\begin{abstract}
This article contains results of the research on religious tourism in the South Moravian and Zlín regions. The aim of this research was to identify new pilgrimage routes. The methodology was based on the implementation of survey interviewers and the design of religious and cultural tourism conceptual strategy. There were 1222 respondents participating in the survey interviewers. The results show that $58 \%$ of them consider 'religious tourism' a visit to pilgrimage places not just by believers and that $43 \%$ of respondents have never been to any pilgrimage. The conceptual strategy focused on the assessment of tourism potential of selected sites and designed 3 new pilgrimage routes: 1) Vranov - Křtiny - Velehrad; 2) Mikulov Břeclav - Mikulčice (connection of St. Jacobs Route and European Cultural Route of St. Cyril and Methodius) and 3) Radhošt' - Rajnochovice - Svatý Hostýn. Three priorities that may serve as a framework for the development of religious tourism in the South Moravian and Zlín regions were set as well.
\end{abstract}

Key words: Religious tourism, pilgrimage route, South Moravian Region, Zlín Region

Souhrn: Tento článek obsahuje výsledky výzkumu náboženského turismu v Jihomoravském a Zlínském kraji. Cílem výzkumu bylo identifikovat nové poutní trasy. Metodologie výzkumu byla založena na terénním dotazníkovém šetření a zpracování koncepční strategie náboženského a kulturního turismu. Terénního dotazníkového šetření se zúčastnilo 1222 respondentů. Výsledky ukazují, že 58 \% respondentů si pod pojmem „poutní turistika“ představuje návštěvu poutních míst, nejen věřícími. Přitom $43 \%$

\footnotetext{
${ }^{1}$ Miroslav Horák, Department of Languages and Cultural Studies, Faculty of Regional Development and International Studies, Mendel University in Brno, Zemědělská 1/1665, 61300 Brno, Czech Republic, e-mail: miroslav.horak.ujks@mendelu.cz

2 Alice Kozumplíková, Department of Environmentalistics and Natural Resources, Faculty of Regional Development and International Studies, Mendel University in Brno, Zemědělská 1/1665, 61300 Brno, Czech Republic, e-mail: alice.kozumplikova@mendelu.cz

${ }^{3}$ Kristína Somerlíková, Department of Applied Statistics and Demography, Faculty of Regional Development and International Studies, Mendel University in Brno, Zemědělská 1/1665, 61300 Brno, Czech Republic, e-mail: somerlik@mendelu.cz

${ }^{4}$ Helena Lorencová, Department of Environmentalistics and Natural Resources, Faculty of Regional Development and International Studies, Mendel University in Brno, Zemědělská 1/1665, 61300 Brno, Czech Republic, e-mail: helena.lorencova@mendelu.cz

${ }^{5}$ Ivana Lampartová, Department of Environmentalistics and Natural Resources, Faculty of Regional Development and International Studies, Mendel University in Brno, Zemědělská 1/1665, 61300 Brno, Czech Republic, e-mail: ivana.lampartova@mendelu.cz
} 
respondentů se nikdy žádné pouti nezúčastnilo. $V$ koncepci zaměřené na zhodnocení turistického potenciálu vytipovaných lokalit jsou navrženy 3 nové poutní trasy: 1) Vranov - Křtiny - Velehrad; 2) Mikulov - Břeclav - Mikulčice (propojení Svatojakubské cesty a Evropské kulturní stezky sv. Cyrila a Metoděje) a 3) Radhošt' - Rajnochovice - Svatý Hostýn.

Klíčová slova: náboženský turismus, poutní trasa, Jihomoravský kraj, Zlínský kraj

\section{Introduction}

Tourism phenomenon is gradually diversifying and generating new industries that try to address the needs of the local population or seek to protect the environment. However, religious tourism does not belong between new trends in travelling.

Religious tourism can be understood as a segment of tourism, which generally helps mitigate seasonal fluctuations. It is usually considered to be a part of the cultural tourism, but it represents rather a specific part, because both forms differ in participants and their motives, as well as from the perspective of scale and the way of using services and leisure activities (Rinschede 1992; Fourie et al. 2015).

There is no uniform definition of religious tourism. According to Olsen and Timothy (2006), it may be understood as a "travel to any place, shrine, building or landscape feature that is deemed, by at least one religious tradition, to be sacred or holy."

Religious tourism destinations are very closely linked to the existence of a relevant cultural and religious infrastructure in a particular area, i.e. major religious buildings, objects or monuments which bind to significant religious and historical events or religious traditions. It includes pilgrimages, as well as visits made to specific religious events in churches, cathedrals and shrines. These places are visited not only for their religious, but also cultural or historical significance.

Much of the analysis of religious travel has concentrated on pilgrimage, including classifications of sites, discussion about the travel patterns of religious tourists, or differentiation between pilgrim groups (Sizer 1999; Shackley and Welton 2008; Michael 2012).

Religious tourism constitutes an integral part of the hard tourist industry, as well as of outdoor tourism and it represents a significant factor in the development of already developed and developing regions (Schejbal 2008).

According to Tarlow (2010), "it is estimated that in the US alone some 25 percent of the travelling public is interested in faith-based tourism. When one adds to this the number of people who travel for faith-based conventions, and faith-based activities such as weddings, bar mitzvahs or funerals, the number become extraordinarily large. World religious travel is one of the fastest growing segments in travel today. Religious travel is estimated at a value of USD 18 billion and 300 million travellers strong."

Such journeys are found in all the great religions of the world. On a global scale, pilgrimage probably attracts 250 million people/year and have recently attracted considerable interest from tourism planners and marketers, who have realized their economic potential (Jackowski, 2000; Digance 2003). Religious tourism and its effects in economic terms was described by Vukonić (1998).

The area of Europe has a considerable potential in terms of religious tourism thanks to its location, historical sights and religious monuments connected to particular activities of the Roman Catholic Church (48\%), Protestantism (12\%), Orthodox Catholic Church (8\%), and less with Sunni Islam and Buddhism (European Commission 2012).

According to Shackley and Welton (2008), "religious tourism has recently seen significant growth in pilgrimage and visits to Marian shrines throughout the European Union. They examine the growth and spatial development of religious tourism in Europe, looking both at issues of 
supply (types of religious sites and routes) and demand (visitor motivation) in the context of the changing religious pattern."

Religious tourism is thriving in Europe, facilitated by better marketing, increasing levels of interest in spiritual matters and easier access. Visitor destinations have become more diversified as a result of the increasing percentage of Muslim, Hindu and Buddhist immigrants coming to EU.

However, it is currently not possible to obtain valid statistics of the religious affiliation in EU. But in many ways this is unimportant, since the vast majority of visitors to European religious sites today have no specifically religious motivation, but may be classified as cultural or historical tourists.

It is the main paradox of religious tourism in Europe nowadays that European Christian sites are attracting increasing visitor numbers at a time when congregation levels at most Christian churches are falling. According to the World Tourism Organization (2015), an estimated 300 to 330 million pilgrims visit the world's key religious sites every year.

Religious tourism in Europe is focused around urban centres, churches, cathedrals and monasteries as well as shrines and pilgrimage routes. Urban centres (e.g. Prague, Paris or Rome) typically contain sacred sites as well as secular visitor attractions. Europe's major shrines (e.g. Lourdes, Fatima, Knock) appeal more to authentic religious tourists or pilgrims (usually within the Roman Catholic tradition) and may often be commercialized (Shackley and Welton 2008).

In the twentieth century, the pilgrimage phenomenon tends toward a blurring of tourism and pilgrimage (Collins-Kreiner 2010). Any real distinction between pilgrimage and tourism is difficult to discern, and pilgrims simply cannot be differentiated from tourists, because both kinds of travellers can be motivated to embark upon journeys and seek out experiences in order to add meaning to their lives.

The increasing importance of religious tourism in Central Europe was confirmed by Nolan and Nolan (1992). Dancák (2005) and Svoboda et al. (2013) described the role of religious tourism in the Slovak Republic. Irimiás and Michalkó (2013) focused on Hungary and Bachvarov (2006, p. 241-255) in the territory of Bulgaria. Information on pilgrimage sites in the Czech Republic was compiled by Šindar (2007) and Vokolek (2010).

The roots of cultural tourism in the Czech territory go back to second half of the 19th century. Working time reduction and related increase in free time have caused unprecedented interest of people in visiting attractive sites in order to relax. The Czech Tourist Club, which is to this day concerned with the marking and promotion of tourist routes, was established in 1888.

Regions with a suitable touristic potential are characterized by a periodic influx of visitors and participants of such forms of tourism are aware of cultural and a so-called "green" approach to visited sites and landscape (Collins-Kreiner and Wall 2007). Religious tourism in Czech regions also contributes to the recovery of yet often underrated potential of religious monuments.

\section{Basic Characteristics of South Moravian and Zlín Regions}

The South Moravian and Zlín regions offer considerable potential for the development of religious tourism (Figure 1).

Among main tourist sights of the South Moravian Region belong the Cathedral of St. Peter and Paul (settlement cathedral of Brno bishopric), important pilgrimage sites such as Krtiny, Vranov or Blatnice pod Svatým Antonínkem. Other frequently visited locations are Assumption of the Blessed Virgin Mary Basilica, a Slavic settlement in Mikulčice, The Way of the Cross on Holy Hill in Mikulov, Porta coeli Convent in Předklášteří or the Benedictine monastery in Rajhrad. 


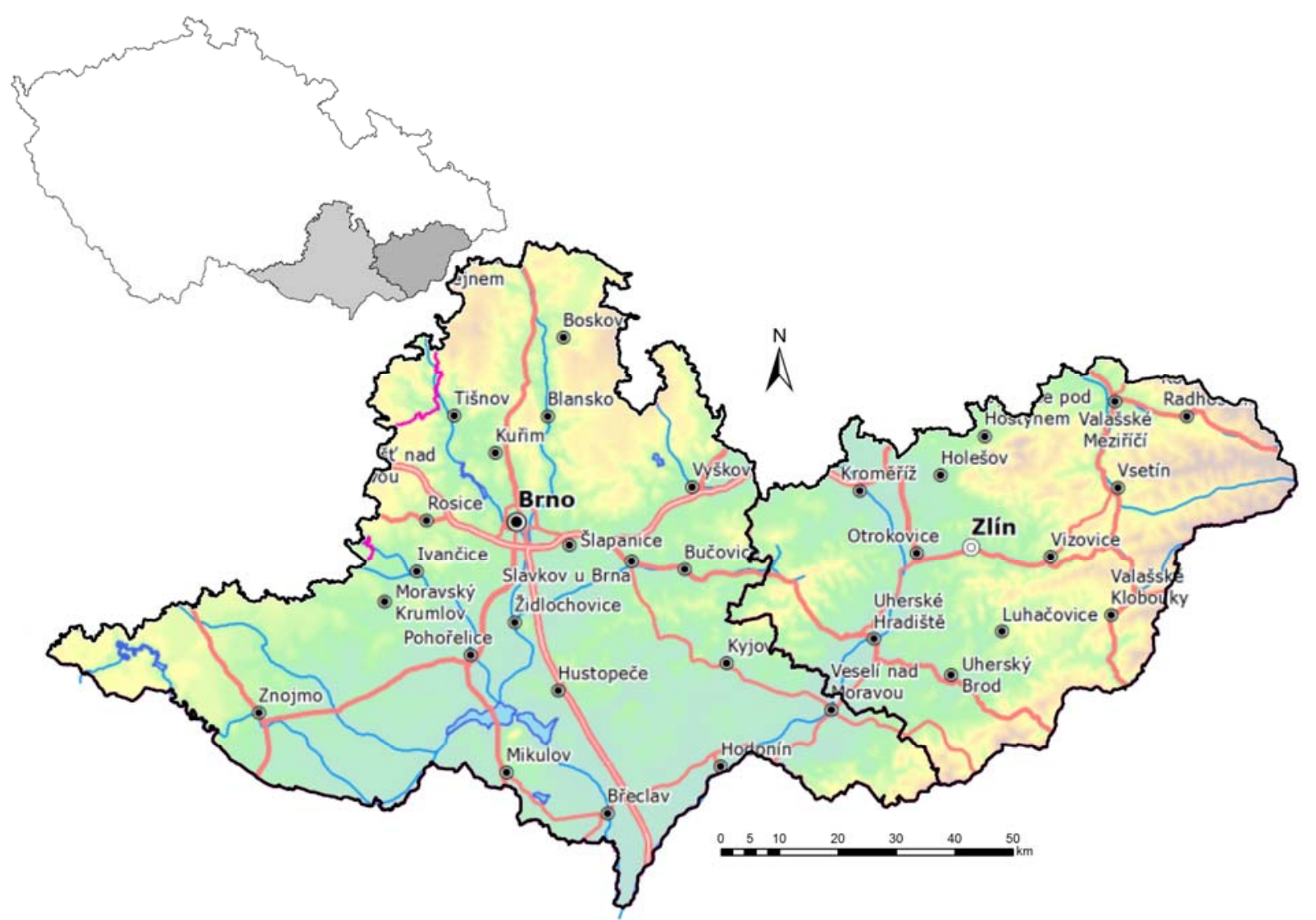

Fig 1. The localization of the South Moravian and Zlín Regions in the Czech Republic. Source: Kozumplíková, A.

In the Zlín region are situated Christian pilgrimage sites St. Hostýn and Velehrad, considered also the most important in the Czech Republic. Furthermore, St. Clements's Keep near Osvětimany, the Dominican monastery in Brod, The Nativity Church of the Virgin Mary in ZlínŠtípa and Provodov, Rajnochovice and Zašová shrines serve here for religious tourism purposes.

An important part of religious tourism in the South Moravian and Zlín regions are Cyril and Methodius monuments. In the South Moravian Region there were identified 56 sites and in the Zlín region 33 such sites. The vast majority of them are churches and chapels dedicated to Christian missionaries Cyril and Methodius. These monuments are concentrated near the axis of Uherske Hradiste (archaeological site Sady) - Staré Město (Monument to Great Moravia) Modrá (archaeological site and an open-air life-size skansen museum) - Velehrad. To a lesser extent, we can find Cyril and Methodius sights in Blanensko (especially chapels) and in the peripheral areas of the Zlín region.

Particular pilgrimage sites are linked together with pilgrimage routes. In the South Moravian and Zlín regions are marked: 1) St. Jacobs Pilgrimage Route (Olomouc - Křtiny, Křtiny - Mikulov), 2) European Cultural Route of Saints Cyril and Methodius (Holy Hill - St. Hostýn - Zlín-Štípa Velehrad, Šaštín - Velehrad (Šindar 2007).

\section{Methodology}

The aim of this research was to evaluate the current state of development of cultural and religious tourism in the South Moravian and Zlín Regions and introduce new pilgrimage routes, designed primarily in connection with $1150^{\text {th }}$ anniversary of St. Cyril and Methodius arrival to Great Moravia. 
Suggested routes in the Czech Republic were originally based on the data recollected within survey interviewers of residents and visitors in a few selected locations: Bystřice pod Hostýnem, Otrokovice, Uherské Hradiště, Velehrad, Křtiny and Vranov (Brno - Country District). ${ }^{6}$

Data were collected using two types of electronic questionnaires. The first one was designed for personal interviews in the above mentioned municipalities and data collection was carried out using the freeware version of iSurvey App for tablets. A second questionnaire designed for data collection on the regional scale and was distributed among respondents online using the online survey software SurveyMonkey.

Both questionnaires were divided into two parts consisting of open format, as well as closed format questions (multiple choice, closed-ended). The first part of each questionnaire was aimed at identifying the views and knowledge of the respondents about the religious tourism. The second part was designed to determine the demographic data (gender, age, education etc.).

Personal interviews were conducted from December 19, 2014 to January 16, 2015 with 1015 inhabitants (of which 511 were permanent residents in the selected municipality) of Bystřice pod Hostýnem, Křtiny, Vranov, Velehrad, Žarošice, Otrokovice, Uherské Hradiště, Brno - Tuřany (at the St. James church) and in Dolní Bojanovice. Questionnaires were completed in homes, churches, pilgrimage sites, touristic routes and public spaces.

Data from both types of questionnaires were later exported to MS Excel, where they were revised and corrected, if any error or typo had been found. Subsequently, the data were processed in Unistat 5.6. In case of all questions, the frequency distribution tables have been calculated for responses to individual variations, as an alternative, as possible. Most of the questions in both types of questionnaires were processed separately. Where the nature of the questions allowed it, calculations were made for all respondents together.

Subsequently, appropriate combinations of identification and detection questions were selected. Then PivotTables and relevant characteristics indicating the dependency of qualitative traits were calculated, especially by the Cramer coefficient (Pecáková, 1995; Príiborová, 1996; Rezanková, 2007). The most difficult and time-consuming was to process a number of open questions, where related answers had to be sorted manually and then counted.

207 questionnaires were filled online electronically within the same period. The first two identical questions in both questionnaires were evaluated together, so the response rate amounts to 1.222. The remaining questions were evaluated separately and their nature is due to low sample size therefore rather complementary.

New pilgrimage routes were proposed by GaREP Ltd. that analyzed provided statistical data and touristic potential of both regions. Further, the conceptual strategy of religious tourism in the area was proposed. Results of questionnaire research served as main source of information on sights that would be of interest to tourists taking a new route.

\section{Results}

The structure of respondents to personal interviews was quite varied - most respondents $(29.7 \%)$ were aged 18 - 30 years, followed by a group of persons over the age of 61 years $(22.2 \%)$. Other age groups were distributed as follows: $31-41$ years (18.6\%), $41-50$ years $(14.2 \%), 51-60$ years $(15.3 \%)$.

Among the interviewees were slightly more women (58.2\%). In terms of education, the majority of interviewees completed high school (58.3\%). Respondents were most often employed $(46.1 \%)$, but also a high proportion of retired people $(23.2 \%)$ and students $(14.3 \%)$ was included.

\footnotetext{
${ }^{6}$ External supplier included in the list also the Žarošice municipality, where in the parish church of St. Ann is a bell named after Cyril and Methodius. In the corners of the presbytery, there are portraits of both saints created by Jan Florian placed on pedestals. The research also took place at unspecified locations in the Hodonín and Brno area.
} 
Due to the age structure of the respondents it is not surprising that almost half of those were married. However, a high proportion (33.6\%) of interviewees were young and single people.

$63.5 \%$ of interviewees confirmed religious affiliation, but this number is very likely to be influenced by polling place. The same is true in the case of questions about how often people go to church, where $23.9 \%$ of interviewees answered "more than once a week".

The structure of the 207 respondents to the online poll was as follows. The predominant proportion of respondents were young people aged 18 - 30 (40.8\%). Second place occupied a group of persons aged 31 - 40 years $(22.8 \%)$. The last group of people, who completed the questionnaire, were over 61 years old (9.7\%). Among the respondents predominated women $(58.9 \%)$.

In terms of education, it is surprising that people with higher education $(49.8 \%)$ slightly predominate over people with secondary education (46.4\%). Almost half of the respondents were employed $(49.0 \%)$ and single $(43.7 \%)$.

$58 \%$ comes were from the South Moravian Region, 39.6\% from the Zlín region and only 5 people were from other regions of the country.

Almost half of the respondents are not religious, but $15.6 \%$ of people did not want to answer this question. Given the high proportion of non-believers, it is logical that the highest proportion of respondents basically never goes to church.

As mentioned above, the primary objective of both questionnaires was to find out what people understood by "religious tourism", and if they had ever participated in it. More than a half of all respondents $(58 \% ; \mathrm{N}=1.222)$ considers religious tourism the visiting pilgrimage sites, not only by believers. Conversely, $34 \%$ of respondents perceived it as a form of tourism only for believers (visiting of pilgrimage sites and participation in pilgrimages).

$43 \%$ of all respondents agreed that they had never participated in the religious tourism. Most of those who have experienced this form of tourism indicated that they were on a pilgrimage in the Czech Republic, as well as abroad. $18 \%$ of respondents stated that they participate in religious tourism only within their region.

$76 \%$ of respondents (with the permanent residence in the place of interviewing, $N=511$ ) contribute to the construction or reconstruction of religious buildings and sites in the municipality where they live. $51.8 \%$ of them believe that religious buildings bring economic benefits to their community (in Krrtiny and Velehrad expressed the same opinion as many as $90 \%$ of respondents). $85.1 \%$ of respondents of survey interviewers are satisfied with the current state of religious buildings or monuments.

Financial contributions of respondents $(\mathrm{N}=1015)$ to the construction or reconstruction of religious buildings and monuments over the past 5 years are ranging from 1,001 to 5,000 CZK. $33 \%$ of persons contributed within this amount range. $12 \%$ contributed over $5,000 \mathrm{CZK}$ and $20 \%$ donated even an amount of $10-50,000$ CZK.

$87 \%$ of online survey respondents $(\mathrm{N}=207)$ consider "pilgrimage site" a place that has historical significance or value. $8 \%$ stated that it is a suitable place for a trip. $9 \%$ of respondents indicated that it is a place meant for religious people only. $5 \%$ of respondents believe it is an architecturally interesting place.

Nearly half of all respondents (44\%) consider religious tourism an attractive and interesting form of traveling. For the other $41 \%$ it is only partially attractive. $15 \%$ do find it neither interesting nor attractive.

There were several major sites noted in the survey and respondents had to indicate, which place they knew. Among the best known to the general public is Velehrad, St. Hostýn, Krrtiny and Holy Hill near Olomouc. Over $60 \%$ of respondents stated that they have already visited Velehrad. The absolute majority of them also visited St. Hostýn and Křtiny.

Respondents of the online survey should also indicate what was relevant to them or vice versa insignificant when planning a visit to a pilgrimage site. As the most important they indicated 
an interest in culture and history, and the availability of information on the site. Other aspects are included in Figure 2.

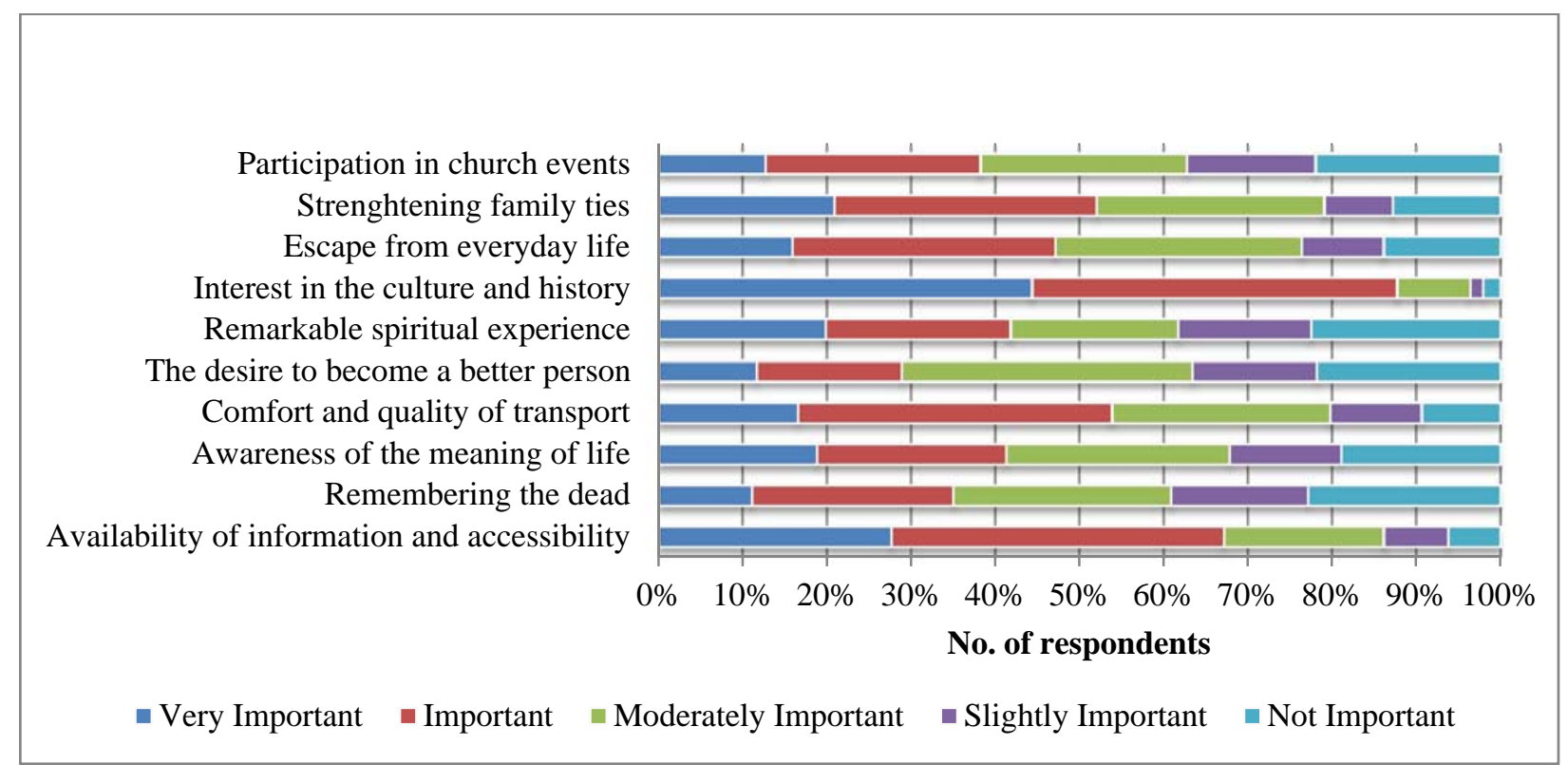

Fig 2. Importance of individual aspects when planning a visit to a pilgrimage site; $N=207$. Source: GaREP Ltd.

\section{Proposal of New Pilgrimage Routes}

The new pilgrimage routes were proposed to create missing links between key pilgrimage sites in the South Moravian and Zlín Region (Vranov, Velehrad, St. Hostýn), with an emphasis on a strong St. Cyril and Methodius tradition. The proposal reflects an effort to strengthen religious tourism in both regions, and to link other important pilgrimage sites (eg. Lutršték, Žarošice, St. Clements's Keep).

Suggested routes follow and complement the St. Jacobs Pilgrimage Route (Suchý - Sloup Jedovnice - Křtiny - Babice nad Svitavou - Bílovice nad Svitavou - Brno - Rajhrad Židlochovice - Uherčice - Popice - Dolní Věstonice - Klentnice - Mikulov) and the European Cultural Route of Saints Cyril and Methodius (St. Hostýn - Rusava - Fryšták - Štípa - Zlín Napajedla - Spytihněv - Huštěnovice - Jalubí - Velehrad - Staré Město - Uherské Hradiště Ostrožská Nová Ves - Ostrožská Lhota - Blatnice pod Svatým Antonínkem - Veselí nad Moravou - Vnorovy - Strážnice - Petrov - Hodonín - Mikulčice). ${ }^{7}$

Three new pilgrimage routes were all connected to the St. Cyril and Methodius tradition. Each route was further specified with regard to the possibility of hiking or cycling, including altitude profile and pictograms informing about their difficulty, distance, time constraints and terrain difficulty for cyclists. A brief description of the proposed pilgrimage routes is included below (Figure 3).

\footnotetext{
7 Intersections of proposed and existing routes are written in bold.
} 


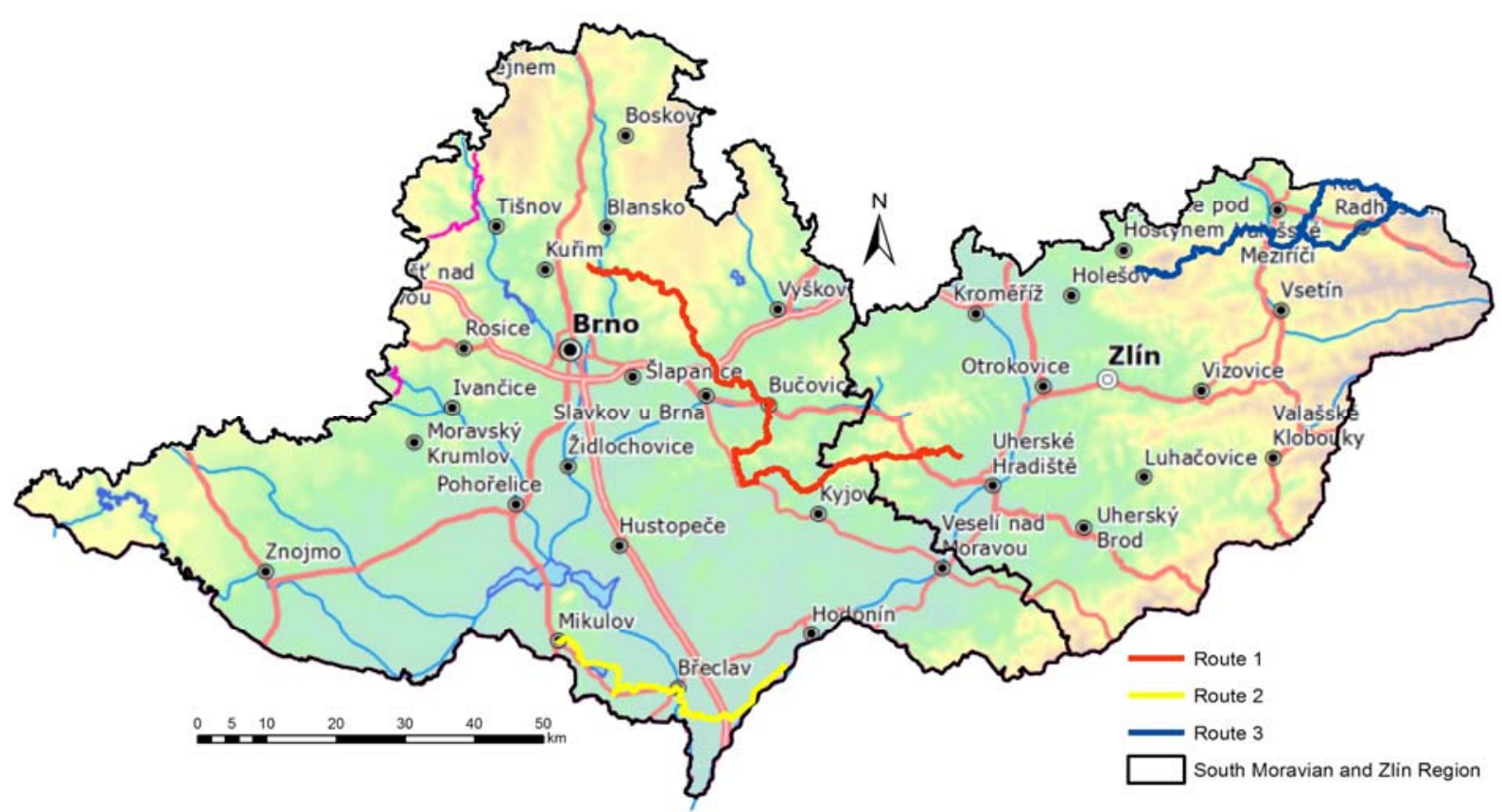

Fig 3. Proposed pilgrimage routes. Source: Kozumplíková, $A$.

Pilgrimage route No. 1 connects Vranov - Křtiny - Velehrad (Figure 4). The route is suitable for both pedestrians and cyclists. Its total length is $109 \mathrm{~km}$. The route is divided into six shorter segments from $14-25.5 \mathrm{~km}$.

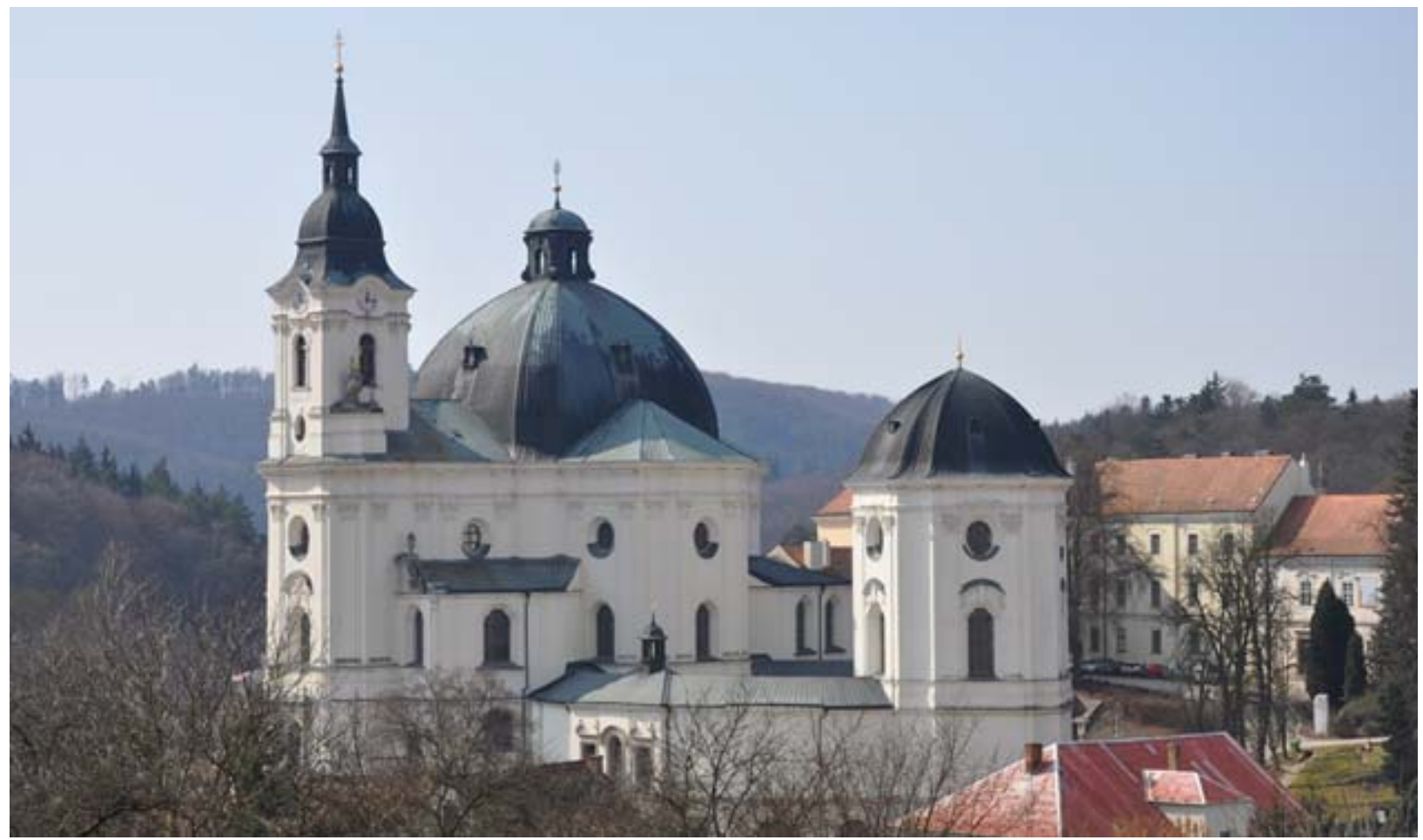

Fig 4. Church of The Name of Virgin Marry in Kr̈tiny. Blansko District, South Moravian Region, Czech Republic. Source: Kozumplíková, A.

Pilgrimage route No. 2 connects Mikulov - Břeclav - Mikulčice and represents of interconnection of St. Jacobs Route and European Cultural Route of St. Cyril and Methodius (Figure 5). It is a pedestrian route that is of course (with the exception of the immediate surroundings of Holy Hill near Mikulov) also good for cycling. The route has a total length of $55 \mathrm{~km}$ and is divided into two shorter sections. 


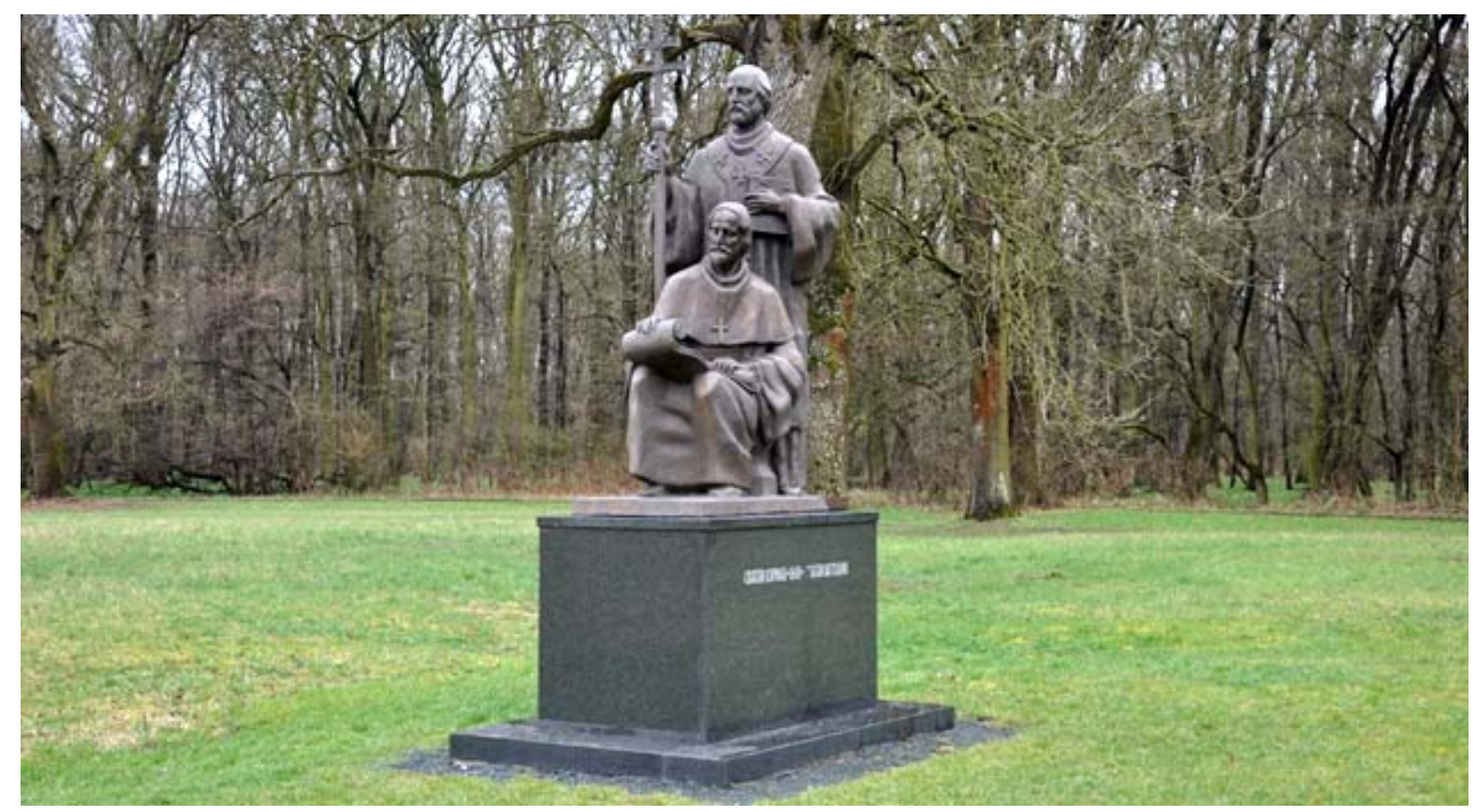

Fig 5. Saints Cyril and Methodius monument in Mikulčice. Source: Kozumplíková, A.

Pilgrimage route No. 3 connects pilgrim sites Radhošt' - Rajnochovice - St. Hostýn (Figure 6). Its total length is $59 \mathrm{~km}$ (through the village Zašová $68.5 \mathrm{~km}$ ). The route is suitable for hiking, in some sections also for cycling. It has been divided into three shorter sections. For further details on proposed pilgrimage routes consult Horák et al. (2015, p. 116-133).

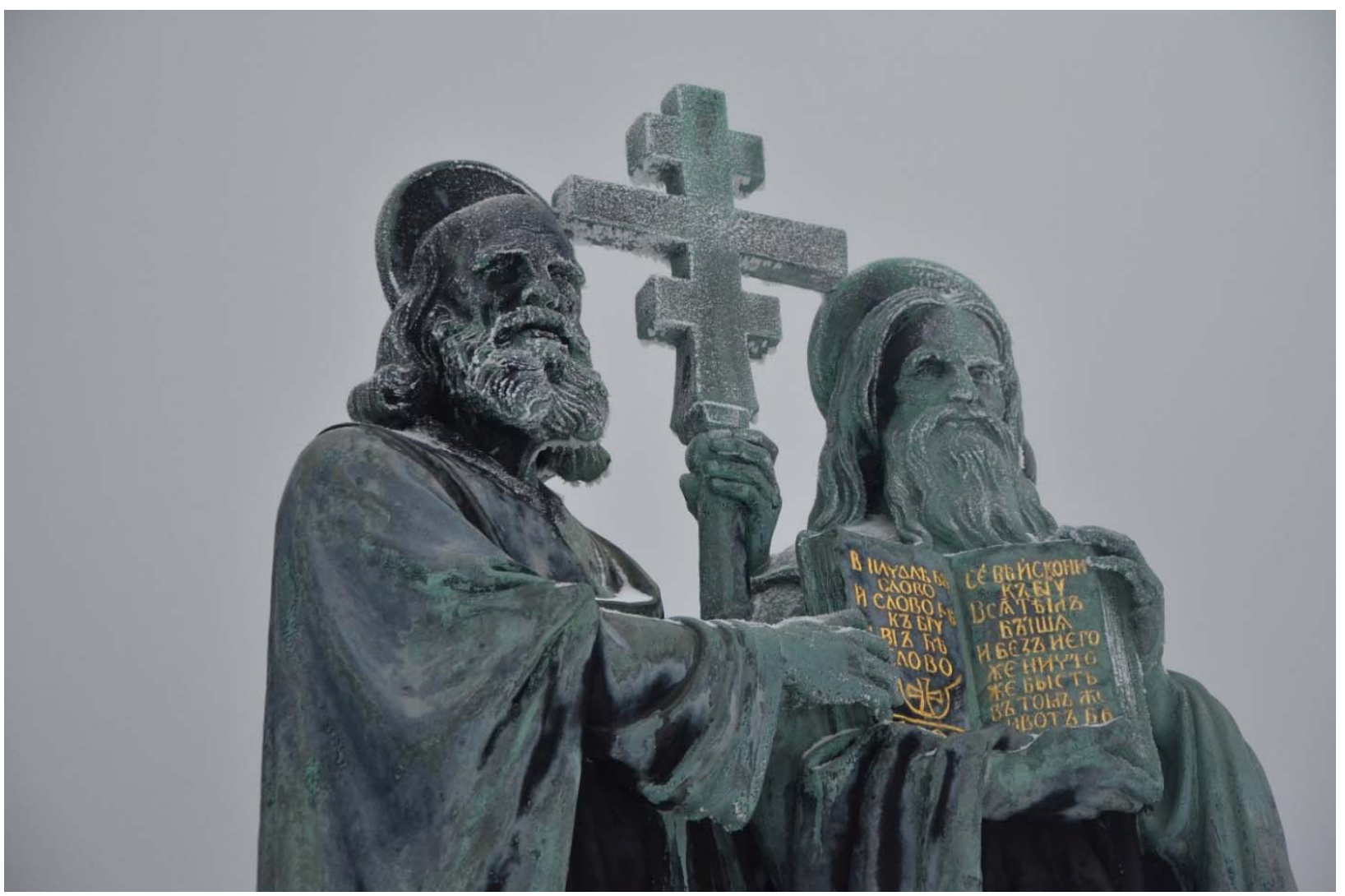

Fig 6. Statue of Ss. Cyril and Methodius on Radhost Hill. Source: Hrabálek, M. 


\section{Conclusions}

The research we have implemented demonstrated that more than a half of all respondents considers religious tourism the visiting pilgrimage sites, not only by believers. Almost the same number of all respondents agreed that they had never participated in the religious tourism. However, they consider it an attractive and interesting form of traveling.

To develop religious tourism in the South Moravian and Zlín regions, we set three priorities. Furthermore, we defined steps for each priority, which would increase the attractiveness of this form of tourism for all groups of population.

The $1^{\text {st }}$ priority is the development of infrastructure for religious tourism. The main part of religious tourism consists of organized pilgrimages, when a group of pilgrims from various parishes travels on a regular annual basis to some pilgrimage site. Most of the pilgrims arrive by bus or car. Youth and younger pilgrims prefer to walk together, one or more days on a common journey. For this reason, it is necessary to build the infrastructure for religious tourism:

1. in transport: parking areas, rest stops, trails etc.;

2. in accommodation: primarily associated accommodation with religious objects, i. e. pilgrim houses, parishes, spiritual centers, etc.).

The $2^{\text {nd }}$ priority is the preparation of marketing products. Promotion of religious tourism could be directed to the area of organized religious tours (pilgrimages, usually organized within annually recurring prescribed deadlines) and individual religious tours (pilgrimages without previously announced terms).

The $3^{\text {rd }}$ priority is the development of partnerships. Coordination and meaningful implementation of measures and possible activities in the area of religious tourism is necessary to ensure the effective cooperation of all stakeholders. Among the key stakeholders may be included:

1. at the international level: cooperation between individual states (especially churches and national institutions supporting the development of religious tourism and international pilgrimage routes);

2. at the national level: CzechTourism, churches (especially the Roman Catholic Church);

3. at the regional level: Tourist Authority South Moravia, Tourist Authority East Moravia, Regional Office of South Moravian Region, the Regional Office of Zlín Region;

4. at the local level: parishes, villages, residents - pilgrims.

In the future, we expect that the proposed pilgrimage routes will be included in the European Cultural Route of Saints Cyril and Methodius.

\section{Acknowledgements}

The authors of this paper are grateful to the provider of financial subsidy for the implementation of the project: "Cyril and Methodius Route for Developing Cultural Activities and Cultural Tourism" (OP SR-CR 2007-2013, Reg. No.: 22410120061). Sincere thanks to Milan Rajčák, Ph.D., Faculty of Mass Media Communications at University of Ss. Cyril and Methodius in Trnava, for his helpful attitude and cooperation on the implementation of individual project activities. It is also our duty to record our thankfulness to Ing. Martin Peterka, Project Manager of the European Cultural Route of Saints Cyril and Methodius, who is helping us to incorporate proposed routes into the wider European framework and contributes to their promotion. The authors wish to thank also to the external suppliers who participated in the project: Everesta, Ltd., for the implementation of survey interviewing, and GaREP Ltd., for the conceptual strategy processing. 
[1] Bachvarov, M. (2006). Tourism in Bulgaria (pp. 241-255), in Hall, D., Smith, M., \& Marciszewska, B., eds., Tourism in the New Europe: The challenges and opportunities of EU enlargement. Wallingford: CABI Publishing.

[2] Collins-Kreiner, N. \& Wall, G. (2007). Evaluating Tourism Potential: A SWOT Analysis of the Western Negev, Israel, Tourism - an International Interdisciplinary Journal 55(1), 5163.

[3] Collins-Kreiner, N. (2010). Geographers and pilgrimages: Changing concepts in pilgrimage tourism research, Tijdschrift voor Economische en Sociale Geografie 101(4), 437-448. DOI: 10.1111/j.1467-9663.2009.00561.x.

[4] Dancák, F. (2005). Náboženský turizmus. Prešov: Petra.

[5] Digance, J. (2003). Pilgrimage at contested sites. Annals of Tourism Research, vol. 30, no. 1 , pp. 143-159. DOI: 10.1016/S0160-7383(02)00028-2.

[6] European Comission 2012, Discrimination in the EU in 2012. Special Eurobarometer 393/ Wave EB77.4 - TNS Opinion \& Social, Directorate-General Justice and DirectorateGeneral Communication.

[7] Fourie, J., Rosselló, J., \& Santana-Gallego, M. (2015). Religion, religious diversity and tourism, Kyklos, 68(1), 51-64. DOI: 10.1111/kykl.12066.

[8] Horák, M., Kozumplíková, A., Somerlíková, K., Lorencová, H., \& Lampartová, I. (2015). Po stopách sv. Cyrila a Metoděje: Návrh nových poutních tras na území Jihomoravského a Zlínského kraje (pp. 116-133), in Čábyová, L., Rajčák, M., eds., Sakrálne pamiatky vo svetle cestovného ruchu. Trnava: Faculty of Massmedia Communication, University of Ss. Cyril and Methodius.

[9] Irimiás, A., \& Michalkó, G. (2013). Religious tourism in Hungary - An integrative framework. Hungarian Geographical Bulletin, 62(2), 175-196.

[10] Jackowski, A., ed. (2000). Selected Research Problems in the Geography of Pilgrimage. Peregrinus Cracoviensis 10. Kraków: Jagellonian University.

[11] Michael, S. (2012). Religion and tourism: Crossroads, destinations and encounters. New York: Routledge.

[12] Nolan, M. L., \& Nolan, S. (1992). Religious sites as tourism attractions in Europe. Annals of Tourism Research. 19(1), 68-78. DOI: 10.1016/0160-7383(92)90107-Z.

[13] Odehnal, F. (1995). Poutní místa Moravy a Slezska. Praha: Debora.

[14] Olsen, D. H. \& Timothy, D. J. (2006). Tourism, religion and spiritual journeys. London and New York: Routledge.

[15] Pecáková, I. (1995). Statistické aspekty terénních průzkumů I., Praha: University of Economic.

[16] Přibová, M. (1996). Marketingový výzkum v praxi. Praha: Grada Publishing.

[17] Rinschede, G. (1992). Forms of religious tourism. Annals of Tourism Research. 19(1), 5167. DOI: 10.1016/0160-7383(92)90106-Y.

[18] Řezanková, H. (2007). Analýza dat z dotazníkových šetření. Praha: Professional Publishing.

[19] Schejbal, C. (2008). Typologie cestovního ruchu. Přerov: College of Logistics.

[20] Shackley, M. \& Welton, R. (2008). Religious tourism in the European Union: Resources and trends. New York: Nova Science Publishers.

[21] Svoboda, J., Šalgovičová, J., \& Polakovič, A. (2013). Religion and tourism in Slovakia. European Journal of Science and Theology. 9(6), 125-132. 
[22] Šindar, J. (2007). Putování po poutních místech Čech, Moravy a Slezska. Kostelní Vydří: Karmelitánské nakladatelství.

[23] Tarlow, P. E. (2010). Religious and pilgrimage tourism. Destination World no. 33, viewed 16 June 2015, http://www.destinationworld.info/newsletter/feature65.html.

[24] Vokolek, V. (2009). Neznámé Čechy - Posvátná místa středních Čech. Praha: Mladá Fronta.

[25] Vokolek, V. (2010). Neznámé Čechy $2^{\text {nd }}$ Volume - Posvátná místa středních Čech. Praha: Mladá Fronta.

[26] Vokolek, V. (2011). Neznámé Čechy $3^{\text {rd }}$ Volume - Posvátná místa severozápadních Čech. Praha: Mladá Fronta.

[27] Vukonic, B. (1998). Religious Tourism: Economic Value or an Empty Box? Zagreb International Review of Economics \& Business. 1(1), 83-94.

[28] World Tourism Organization (2015). Compendium of Tourism Statistics, Data 2009-2013, viewed 16 June 2015, http://www.e-unwto.org/doi/pdf/10.18111/9789284416387. 